\title{
DEVELOPMENT OF WARNING CRITERIA FOR LAHAR FLOW DISASTER IN GENDOL RIVER AREA OF MOUNT MERAPI
}

\author{
Ernowo Ary Fibriyantoro \\ Large River Basin Organization of Serayu Opak, Yogyakarata, INDONESIA \\ pheb.cappone@gmail.com
}

\begin{abstract}
The eruption of Mount Merapi in 2010 leads to the lahar flow disaster in the region of the mountain slopes. Due to the impact caused by the lahar flow, it is important to develop warning criteria for lahar flow disaster with a simple method corresponding to the limitation of existing data and parameters. One of the methods is by analyzing rainfall data to predict the occurrence of lahar flow in Gendol River. It applies the setting of standard rainfall for warning and evacuation of sediment disasters based on Guidelines for the Development of Warning and Evacuation System against Sediment Disasters in Developing Countries, published by the Ministry of Land, Infrastructure, and Transport (MLIT) Infrastructure Development Institute - Japan, 2004. This study analyzed the critical line (CL) which can be used to predict the occurrence of lahar flow based on the rain characteristics namely working rainfall and rainfall intensity. Furthermore, it can be established by warning line (WL) and the evacuation line (EL) as a basis for determining the standard rainfall for warning (R1) and standard rainfall for evacuation (R2). The value of R1 obtained $\pm 6 \mathrm{~mm}$ and $\mathrm{R} 2 \pm 29 \mathrm{~mm}$. The value of R1 and R2 are strongly influenced by the availability of rainfall data and occurrence of lahar flow. The results of this research were expected to be used as input for the warning criteria development of early warning system lahar flow disaster on the slopes of Mount Merapi, particularly in the area of Gendol River.
\end{abstract}

Keywords: lahar flow, critical line, standard rainfall, Gendol River

\section{INTRODUCTION}

After the eruption of Mount Merapi in 2010, according to BPPTKG data, at least 140 million $\mathrm{m} 3$ of volcanic material was ejected and stacked on the slope of Mount Merapi. When heavy rainfall happens, deposited sediment material is transported by the surface runoff, thus leads the lahar flow disaster causing loss of life and various damages to the infrastructures, farmland and residential areas. Lahar flow in the region of Mount Merapi after the eruption in 2010 was assessed to be potential to occur in a rainy season, and still, threaten the people living along rivers from Mount Merapi including of Gendol River.

Due to the impact caused by these natural disasters, reduction of the incidence of fatalities should be developed warning criteria of lahar flow disaster with a simple method corresponding to the limitation of existing data and parameters. Rainfall data analysis is one of the methods commonly used to predict the occurrence of lahar flow.

This research aims to develop warning criteria of potential occurrence of lahar flow disaster in Gendol River based on working rainfall and rainfall intensity, then Critical Line, Warning Line, and Evacuation Line can be developed as a basis for determining the standard rainfall for warning (R1) and standard rainfall for evacuation (R2). The results of this research were expected to be used as input for the warning criteria development of early warning system lahar flow disaster on the slopes of Mount Merapi, particularly in the area of Gendol River.

\section{CRITICAL LINE FOR LAHAR PREDICTION}

Lahar is a rapid movement of a mixture of water and solid material such as large rocks, sand, gravel and etc. from the volcanic eruption (Kusumobroto, 2011). Kusumobroto (2013)defined lahar into two terms, i.e. lahar letusan and lahar hujan. Lahar letusan is formed from volcanic eruptions that have crater lakes, such as Mount Kelud in East Java. While Lahar hujan is formed of pyroclastic material deposits which becomes saturated due to water volume supply from rainfall in adequate amounts, such as the occurrence of lahar flow in Mount Merapi. The three main components in the formation of the lava flow are slope, materials, and water.

By determining standard rainfall, it is possible to predict the occurrence of debris flow or slope failure from rainfall data, but a different level of the accuracy depends on the gathered data. Although it is known that hourly rainfall or 10-minute rainfall in real time is the most appropriate method to determine an accurate estimation of the occurrence of sediment disaster, but recorded data available in developing countries are usually daily rainfall. Sometimes, the measurement is 
carried out in remote areas. From this adverse situation as well as the inadequacy of the existing rainfall data, this method is seemingly beneficial for warning and evacuation systems in developing countries.

Critical line curve separates rainfall data at the time of debris flow occurrence (causing rainfall) and rainfall data which not directly caused the occurrence of debris flow (non-causing rainfall). A critical line is an approach of warning and evacuation method used to predict the probability of lahar flow occurrence for early warning of lahar flow disaster application. There are three approaches in creating critical line (MLIT, 2004), namely: (1) Method A: hourly rainfall as ordinate while working rainfall as abscissa, (2) Method B: effective rainfall intensity as ordinate while working rainfall as abscissa; (3) Methods Committee: working rainfall within 72-hours half-life as abscissa while working rainfall within 1.5 hours half-life as ordinate.

\section{GENERATING WARNING AND EVACUATION LINE}

The research was conducted in the Gendol River watershed which is administratively located in Sleman Regency, Yogyakarta Province. It is bordered by Mount Merapi in the north, Woro watershed in the east, and Opak watershed in the south and the west (see Figure 1)

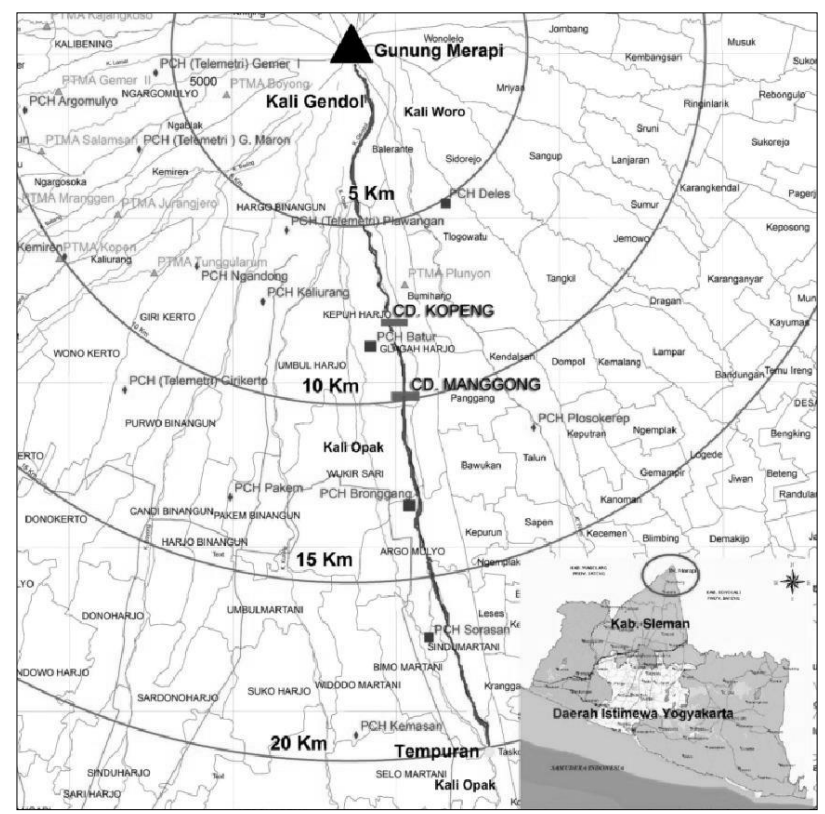

Figure 1 Research location

This research used secondary data, namely: (1) hourly rainfall data of 2010-2012 at Batur Station, Deles Station, and Bronggang Station, (2) occurrence data of lahar flow monitoring result after 2010 Mount Merapi eruption in Gendol River. Rainfall data and occurrence data of lahar flow were used to generate a series of rain in which the lahar flow occur (causing rainfall) and a series of rain in which lahar flow did not occur (noncausing rainfall) taking into account in form 1 and 2 for the calculation of the other rainfall index. Stages of data analysis performed in this study are as follows:

\section{a) Determination of a series of rain}

The series of rain were defined by continuous rainfall limited by not-rainfall duration for 24 hours or more before and after the rainfall sequence. The total amount of rainfall during that period was defined as Continuous Rainfall $\left(\mathrm{R}_{\mathrm{C}}\right)$. One week rainfall before the start of the series was defined as Antecedent Rainfall $\left(\mathrm{R}_{\mathrm{A}}\right)$, whereas the 24-hour rainfall is calculated from the start of the series of rain determined as antecedent rainfall in one day before $\left(\mathrm{d}_{1}\right)$, the rainfall occurred within 24 to 48 hours prior to series of rainfall is defined as antecedent rainfall two days previous $\left(\mathrm{d}_{2}\right)$, and so on to seven earlier days $\left(d_{7}\right)$.

b) Calculation of Antecedent Working Rainfall $\left(\mathrm{R}_{\mathrm{WA}}\right)$ and Working Rainfall $\left(\mathrm{R}_{\mathrm{W}}\right)$

$\mathrm{R}_{\mathrm{WA}}$ was obtained by summing up the multiplication between deduction coefficient $\alpha_{2}$ with $\mathrm{d}_{2}$ and so forth until $\alpha_{7}$ with $d_{7} . R_{W}$ was obtained from cumulative rainfall and $\mathrm{R}_{\mathrm{WA}}$.

\section{c) Calculation of rainfall intensity}

Rainfall intensity causing lahar flow was analyzed using 1-hour rainfall intensity just before the occurrence of lahar flow, whereas non-causing rainfall was calculated using maximum hourly rainfall intensity in a series of rain which did not cause a lahar flow.

d) Plotting graph of working rainfall vs. rainfall intensity

In the case of causing rainfall data, "working rainfall up to 1 hour before the flood" as the $\mathrm{x}$-axis, while the "1-hour rainfall intensity immediately before the flood" as the y-axis. In the case of non-causing rainfall data, "The working rainfall up to before the start of a maximum hourly rainfall" as the y-axis, while the maximum hourly rainfall intensity in a series of rain as the y-axis.

e) Calculation of $R_{\mathrm{H} 1 \mathrm{M}}$ and $\mathrm{R}_{\mathrm{H} 2 \mathrm{M}}$

f) The past maximum 1-hour rainfall is shown by $\mathrm{R}_{\mathrm{HIM}}$ while the past maximum 2-hour rainfall is shown by $\mathrm{R}_{\mathrm{H} 2 \mathrm{M}}$. 
g) Generating Critical Line (CL), Warning Line (WL) and the Evacuation Line (EL)

CL was drawn by separating collection points of causing rainfall and non-causing rainfall in the graph of working rainfall vs. rainfall intensity by a straight line. EL set from $\mathrm{R}_{\mathrm{H} 1 \mathrm{M}}$ drawn a horizontal line intersecting with CL. EL is perpendicular to a vertical line from that intersection point. While $\mathrm{WL}$ is a straight line obtained by parallel displacement of the EL towards the left side by "RH $\mathrm{H}_{2 \mathrm{M}}-\mathrm{RH}_{1 \mathrm{M}}$ ".

h) Generating standard rainfall for warning (R1) and standard rainfall for evacuation (R2)

$\mathrm{R} 1$ is the value of working rainfall at the intersection of the $\mathrm{WL}$ on the $\mathrm{X}$-axis, while $\mathrm{R} 2$ is the value of working rainfall at the intersection $\mathrm{EL}$ on the $\mathrm{X}$-axis.

\section{RESULTS AND DISCUSSIONS}

\subsection{Determination and Calculation of Series of Rain}

Terms of series of rainfall causing lahar flow occurrence in Japan is the depth of rainfall $\geq 80 \mathrm{~mm}$ or rainfall intensity $\geq 20 \mathrm{~mm} /$ hour on one station (Ministry of Land, Infrastructure and Transport, 2004). Geographical and climatic conditions in Indonesia, especially since characteristics of rainfall in Mount Merapi is different with Japan. In the case of Gendol River, many lahar flow flood events occurred during the depths of rainfall $\leq 80 \mathrm{~mm}$ rain (Fitriyadi, 2012). So, the term of rainfall $\geq 80 \mathrm{~mm}$ of rain cannot be used as a determination for the occurrence of lahar flow in this study. Hourly rainfall data containing a series of rain will be analyzed and checked by the lahar flow occurrence data whether including the causing rainfall data or non-causing rainfall data. If there is a lahar flow occurrence in its series of rain then the data will be included in the calculation causing rainfall and for non-occurrence data entered into the calculation of non-causing rainfall.

\section{a) Calculation of causing rainfall}

Rainfall index which was used in the calculation of causing rainfall namely: (1) continuous rainfall $\left(\mathrm{R}_{\mathrm{C}}\right)$, (2) antecedent rainfall $\left(\mathrm{R}_{\mathrm{A}}\right)$, (3) antecedent working rainfall $\left(\mathrm{R}_{\mathrm{WA}}\right)$, (4) working rainfall $\left(\mathrm{R}_{\mathrm{W}}\right)$ to 1 hour prior to lahar flow, (5) 1-hour rainfall immediately before lahar flow.

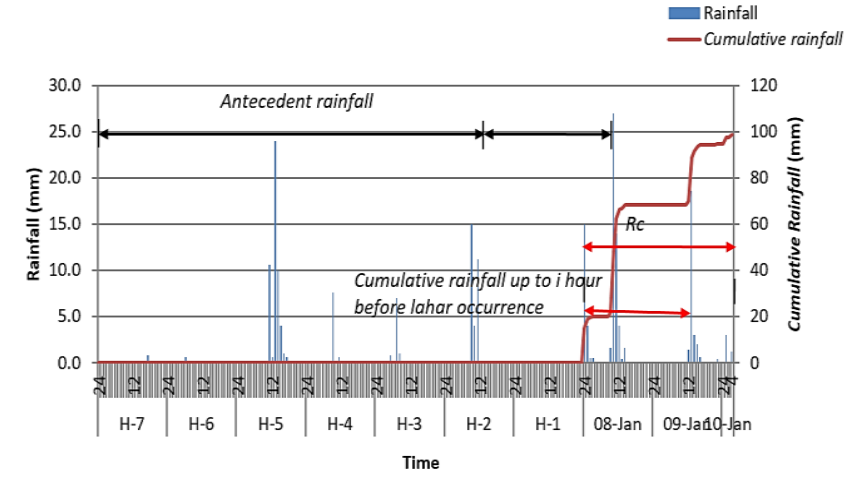

Figure 2. Series of rain (causing rainfall) at Batur Station during 8-10 January 2011

\section{b) Calculation of non-causing rainfall}

Rainfall index which was used in the calculation of non-causing rainfall namely: (1) continuous rainfall $\left(\mathrm{R}_{\mathrm{C}}\right)$, (2) antecedent rainfall $\left(\mathrm{R}_{\mathrm{A}}\right)$, (3) antecedent working rainfall $\left(\mathrm{R}_{\mathrm{WA}}\right),(4)$ working rainfall $\left(\mathrm{R}_{\mathrm{W}}\right)$ until just before the maximum precipitation, (5) maximum hourly rainfall which did not cause lahar flow.

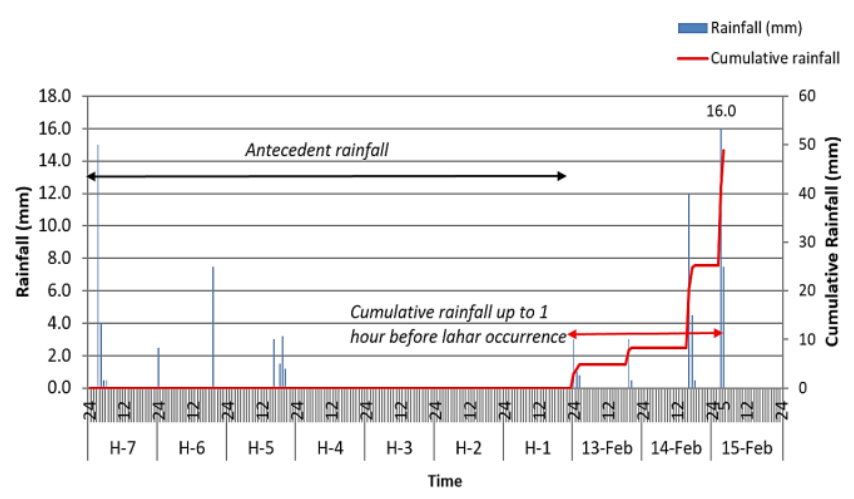

Figure 3. Series of rain (non-causing rainfall) at Batur Station during 13-15 February 2011

\subsection{Critical Line of Gendol River Setting}

Deles Station is located at the upstream of the river and closer to the source of deposited sediment comparing to Batur Station and Bronggang Station location. However Deles Station is far away from Gendol River, thus it is considered less representative if it is used as a reference for the setting critical line of Gendol River, while Bronggang station is located in the most downstream area and far away from the location of the sediment source. Therefore, rainfall station taken into account is where considered less representative to rainfall events that trigger lahar flow in the upstream of Mount Merapi. Location of Batur Station is between 5$10 \mathrm{~km}$ radius from the summit of Mount Merapi which is the zone of sediment production by elevation +745 $\mathrm{m}$ and close to Gendol River. Rainfall data at Batur Station was limited until June 2011 only, the data is 
discontinued by then due to equipment damage. Based on these considerations and by utilizing existing limited data, so Batur Station was selected as a representative station for reference in the setting of critical line Gendol River.

The critical line was generated using rainfall data from Batur Station by separating collection points of causing rainfall and non-causing rainfall in the graph of working rainfall vs. rainfall intensity by a straight boundary line (critical line). Rainfall index is shown in Table 1.

Table 1 Rainfall index

\begin{tabular}{lll}
\hline $\begin{array}{l}\text { Rainfall } \\
\text { Data }\end{array}$ & Axis & Ordinate \\
\hline $\begin{array}{l}\text { Causing } \\
\text { Rainfall }\end{array}$ & $\begin{array}{l}\text { working rainfall up to } \\
1 \text { hour before the } \\
\text { occurrence of lahar } \\
\text { flow }\end{array}$ & $\begin{array}{l}\text { 1-hour rainfall } \\
\text { intensity } \\
\text { immediately before } \\
\text { the occurrence of } \\
\text { lahar flow } \\
\text { Maximum hourly }\end{array}$ \\
$\begin{array}{l}\text { Non- } \\
\text { rainfing }\end{array}$ & $\begin{array}{l}\text { The working rainfall } \\
\text { of a maximum hourly } \\
\text { rainfall }\end{array}$ & $\begin{array}{l}\text { rainfall intensity in } \\
\text { a series of rain }\end{array}$ \\
\hline
\end{tabular}

The critical line was generated based on the outermost point of the three causing rainfall data on January 3, 2011, January 24, 2011, and March 19, 2011. The critical line is the boundary line between the safe zone in which lahar flow may not happen and unsafe zone which has potential to lahar flow. Critical line based on Batur Station can be seen in Figure 4.

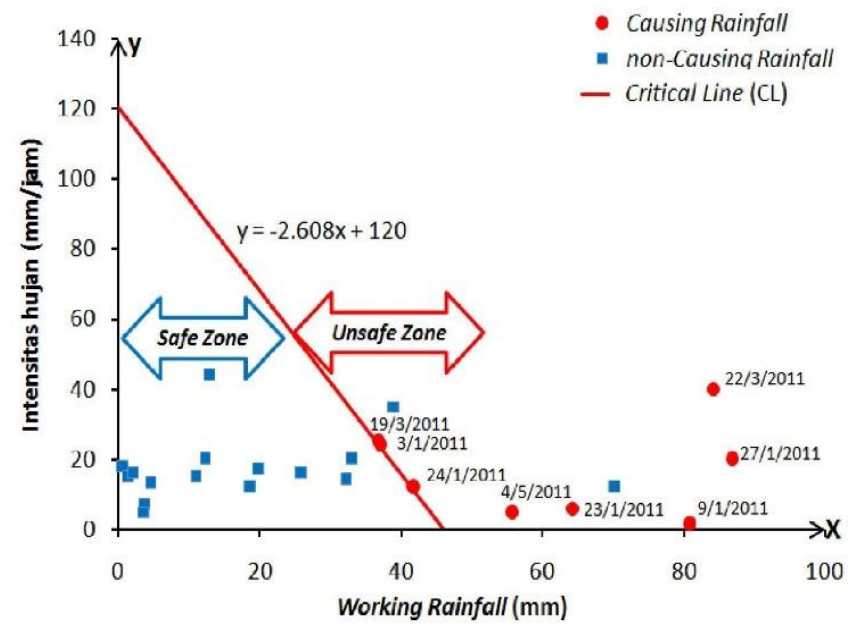

Figure 4. Critical Line Gendol River of Batur Station

\subsection{Evacuation Line Dan Warning Line Setting}

Before evacuation line and warning line was set, the value of past maximum 1-hour rainfall $\left(\mathrm{RH}_{1 \mathrm{M}}\right)$ and past maximum 2-hour rainfall $\left(\mathrm{RH}_{2 \mathrm{M}}\right)$ need to be specified.
Obtained RH1M was $44 \mathrm{~mm}$ and RH2M was 67 $\mathrm{mm} / 2$ hour then they were plotted on a graph of the correlation between working rainfall and rainfall intensity (see Figure 5). Draw a horizontal line (parallel to the $\mathrm{x}$-axis) from RH1M on the ordinate until being intersected with CL. From the intersection point, EL was obtained by drawn perpendicular (parallel to the yaxis. Intersection point on EL with the $\mathrm{x}$-axis is the value of R2 (29 mm) as rainfall for evacuation. WL is obtained by parallel displacement of the EL toward the left side by $\mathrm{RH}_{2 \mathrm{M}}-\mathrm{RH}_{1 \mathrm{M}}(23 \mathrm{~mm})$. WL intersection point with the $\mathrm{x}$-axis is the value of $\mathrm{R} 1(6 \mathrm{~mm})$ as rainfall for the warning, as shown in Figure 3. So based on rainfall at Batur Station, standard rainfall for warning issuance $(\mathrm{R} 1)= \pm 6 \mathrm{~mm}$, and standard rainfall for evacuation $(\mathrm{R} 2)= \pm 29 \mathrm{~mm}$.

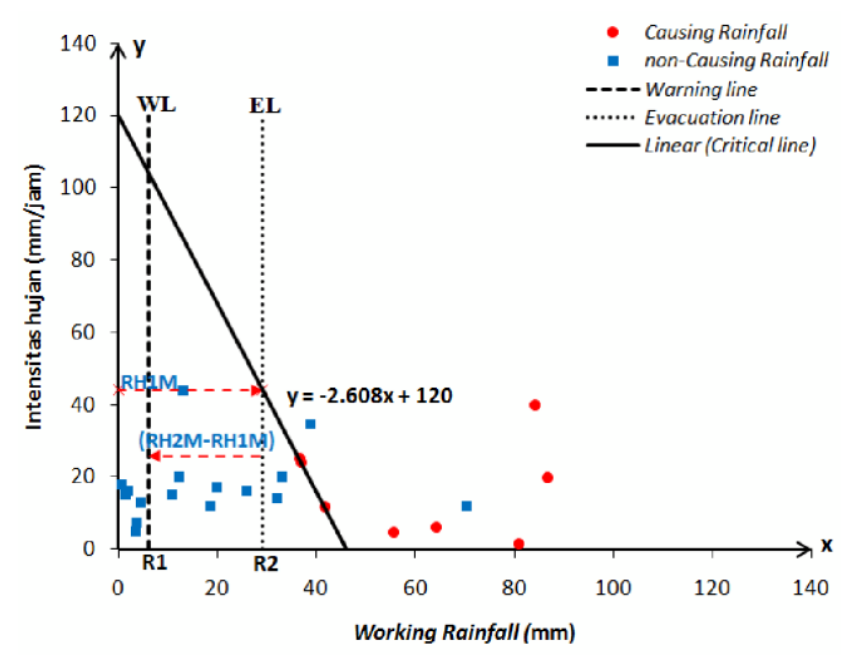

Figure 5 Setting of CL, WL, and EL in Batur Station

The limited rainfall data and lahar flow occurrence data can be obstacles in the setting of critical line. The value of R1 and R2 are strongly influenced by the adequacy of rainfall data and the occurrence of lahar flow. In Figure 2, CL line was drawn by three points, so that established values of R1 and R2 relatively small. For further research, longer data of rainfall and occurrence of lahar flow from real-time observation and the use of representative rainfall stations which is more performing the real condition considering the very high rainfall variability in the region of Mount Merapi is necessary to conduct. Standard rainfall for warning and evacuation were established in this research. The value will be easily exceeded by the measured cumulative rainfall so that recommendations for warning issuance and evacuation instructions will be issued too often though the occurrence lahar flow will not surely occur. Therefore, it is necessary to verify and update the rainfall data and occurrence data of lahar flow continuously in order to get good warning criteria. Warning criteria in this study should not stand alone, in 
order to run an effective early warning efforts, it should be integrated by early warning system equipment such as IP cameras, wire sensor, vibration sensor, AWLR and others which are transmitted real time to a master station, then processed by operators in order to establish an accurate warning criteria.

\section{CONCLUSIONS}

\subsection{Conclusions}

a) Based on rainfall data of Batur Station and lahar flow occurrence one year after the Merapi eruption (2010-2011), critical line, warning line and evacuation line can be established to obtain the value of standard rainfall for warning is about 6 $\mathrm{mm}$ and standard rainfall for evacuation is approximately $29 \mathrm{~mm}$ from the analysis of working rainfall and rainfall intensity.

b) Limited causing rainfall data caused difficulty in delineation the appropriate CL line. The value of $\mathrm{R} 1$ and R2 is strongly influenced by the adequacy of rainfall data and the occurrence of lahar flow.

c) Causing rainfall data with small value of working rainfall may exceed measured rainfall much more often than real situation if it is used as a reference for setting of CL

d) In order to obtain a good warning for lahar flow predictions in the future, it is necessary to verify and update the rainfall data and lahar flow occurrence continuously.

\subsection{Recommendations}

a) Further research with longer data collection from real-time observation considering the location of rain gauge station and observation point of lahar flow occurrence with the location of the source sediment was important to conduct. Kaliadem Station is recommended to be used as a reference in generating critical line if the data is sufficient because it is more applicable for Gendol River case.

a) The setting of CL, WL, and EL should be tested using rainfall data and occurrence data of lahar flow 3 months, 1 year and 2 years post-eruption. So it can be known the comparison of warning criteria for each period and the potential events for lahar flow to the characteristics of deposited sediment changing by time.

b) Resulted warning criteria cannot stand alone. For recommendations issuance / cancellation of warning and evacuation, some instructions should be supported by other information such lahar flow monitoring by visual observation, camera, wire sensor, vibration sensor, and others. c) Further research on determining the eduction coefficient in the calculation of Antecedent Working Rainfall $\left(\mathrm{R}_{\mathrm{WA}}\right)$ is necessary. It can be used the other half-life such as half-life 2 days and 3 days.

\section{REFERENCES}

Fitriyadi, 2012. Analysis of Effective Rainfall Intensity and Working Rainfall for Basic Warning Criteria Development on Lahar Flow Event. Civil Engineering Forum Journal.

Kusumobroto, H., 2011. Banjir dan Aliran Debris [Flood and Debris Flow], Yogyakarta: MPBA Universitas Gadjah Mada.

Kusumobroto, H., 2013. Aliran Debris dan Lahar [Lahar and Debris Flow]. 1st ed. Yogyakarta: Graha Ilmu.

Ministry of Land, Infrastructure and Transport, 2004. Guidelines for Development of Warning and Evacuation System against Sediment Disaster in Developing Countries, Japan. Infrastructure Development Institute. 
[this page intentionally left blank] 